\title{
PRECLASSIC AND CLASSIC MAYA INTERREGIONAL AND LONG-DISTANCE EXCHANGE: A DIACHRONIC ANALYSIS OF OBSIDIAN ARTIFACTS FROM CEIBAL, GUATEMALA
}

\author{
Kazuo Aoyama
}

\begin{abstract}
Diachronic analysis of obsidian artifacts collected from Ceibal, Guatemala, can illuminate long-term patterns and changes in the Preclassic and Classic Maya interregional and long-distance exchange systems. For this analysis sources of all obsidian artifacts were identified by a combination of pXRF of a sample of 5,375 obsidian artifacts and visual examination of 7,073 artifacts. The interregional exchange of large polyhedral cores of obsidian from the Maya highlands and local production of pressure blades began after the rise of political complexity at Ceibal, by the early Middle Preclassic Real 3 phase (775-700 B.C.). El Chayal obsidian was heavily used during the early Middle Preclassic period, but San Martín Jilotepeque was the principal source of obsidian in the late Middle Preclassic, Late Preclassic, and Terminal Preclassic periods. Procurement of large polyhedral cores of obsidian from the Maya highlands increased over the same period. Obsidian was also imported in the form of nodules for the production of percussion flakes during the Preclassic period. Throughout the Classic period obsidian was imported mainly in the form of more prepared polyhedral cores that were reduced into pressure blades at Ceibal, and El Chayal resumed its place as the principal source of obsidian. This period also saw long-distance exchange of finished obsidian artifacts from highland Mexico. Interregional exchange of obsidian from the Maya highlands was of great economic significance for the inhabitants of the community and was more crucial for the development of lowland Maya civilization than was long-distance exchange.
\end{abstract}

El presente artículo discute los resultados del análisis diacrónico de los artefactos de obsidiana recolectados en Ceibal, Guatemala, con el fin de clarificar el patrón a largo plazo y los cambios en el sistema de intercambio interregional y a larga distancia entre los mayas del Preclásico y Clásico. Las fuentes de todos los artefactos de obsidiana fueron identificadas por medio del análisis de fuorescencia de rayos X portátil ( $p X R F)$ de una muestra de 5,375 artefactos de obsidiana y del análisis visual de los 7,073 artefactos restantes. El intercambio interregional de núcleos poliédricos grandes de obsidiana de las tierras altas mayas y la producción local de navajas a presión se iniciaron después del desarrollo sociopolítico de Ceibal durante la fase Real 3 (775-700 a.C.) del período Preclásico Medio temprano. La obsidiana de El Chayal fue usada intensivamente durante el período Preclásico Medio temprano, mientras que San Martín Jilotepeque fue la fuente principal de obsidiana durante los períodos Preclásico Medio tardío, Preclásico Tardío y Preclásico Terminal. Desde la fase Real 3 del Preclásico Medio temprano hasta el período Preclásico Terminal, la obtención de núcleos poliédricos grandes de obsidiana de las tierras altas Mayas se incrementó a través del tiempo, mientras que la obsidiana también fue importada hacia Ceibal en forma de nódulos para la producción de lascas por percusión durante el período Preclásico. En contraste, a lo largo del período Clásico la obsidiana fue importada principalmente en forma de núcleos poliédricos más preparados que fueron transformados en navajas por presión en Ceibal. El Chayal volvió a ser la mayor fuente de obsidiana en Ceibal durante el período Clásico. El intercambio a larga distancia de artefactos terminados de obsidiana de las tierras altas de México fue de importancia social y simbólica, más que económica, durante el período Clásico. El intercambio interregional de obsidiana de las tierras altas mayas tuvo una gran importancia económica para los habitantes de la comunidad. Este tipo de intercambio fue más significativo para el desarrollo de la civilización maya en las tierras bajas comparado al intercambio a larga distancia.

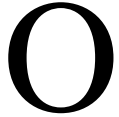
bsidian, a volcanic glass used by the ancient Maya for manufacturing utilitarian cutting implements such as blades and flakes, occurs naturally in Mesoamerica only in the volcanic highlands. Each obsidian source is chemically distinct, and many sources can be distinguished based on instrumental attributions and optical criteria. For this reason obsidian has

Kazuo Aoyama $\square$ Faculty of Humanities, Ibaraki University, Bunkyo 2-1-1, Mito, Ibaraki, 310-8512, Japan (kazuo.aoyama.1@vc.ibaraki.ac.jp)

Latin American Antiquity 28(2), 2017, pp. 213-231

Copyright (C) 2017 by the Society for American Archaeology doi:10.1017/laq.2017.2 
been extremely useful for studying interregional and even long-distance exchange, including the Tehuantepec trans-isthmian exchange. With a large database of geological source samples and many years of studies, laboratories such as the University of Missouri Research Reactor (MURR) have established an outstanding record of success in obsidian provenance research (e.g., Glascock 2002; Glascock et al. 1998). The identification of the sources of artifacts has usually been accomplished through neutron activation analysis (NAA), X-ray fluorescence (XRF), and other technologies, such as inductively coupled plasma mass spectrometry (ICP-MS). Although NAA and ICP-MS are more accurate than XRF in detecting elements in very small and thin pieces of obsidian artifacts, both technologies incur relatively high per sample costs, are potentially destructive, and require the export of artifacts for analysis (Feinman et al. 2013). Moreover, small sample sizes and inappropriate sampling methods often impede efforts to study obsidian distribution patterns (Drennan et al. 1990:180). Recently, Moholy-Nagy and coauthors (2013) used portable X-ray fluorescence (pXRF) to source a large sample of 2,235 obsidian artifacts from Tikal, Guatemala. Although their total sample of instrumental attributions is much larger than any previous study conducted in the Maya area, it represents much less than 4 percent of the total number of obsidian artifacts recorded from the site by the University of Pennsylvania and other archaeological projects and does not constitute a representative sample of what was brought to Tikal (Moholy-Nagy et al. 2013:74). It is my contention that we should and can study broader issues of prehistoric Maya economy, such as production, consumption, and exchange, by analyzing a large representative sample of obsidian artifacts from a diachronic perspective.

I discuss the results of diachronic analyses of an entire collection of 12,448 obsidian artifacts from Ceibal in order to shed light on changing long-term patterns in the Preclassic and Classic Maya interregional and longdistance exchange system (Figure 1). Sources of all obsidian artifacts from Ceibal were identified by a combination of pXRF of a large sample of 5,375 obsidian artifacts and visual examination of the remaining 7,073 artifacts (Figure 2; Tables 1 and 2; Supplemental Table 1).

There is a particularly conspicuous lacuna in empirical studies dealing with obsidian production and exchange during the Middle Preclassic period (1000-350 B.C.) in the Maya Lowlands. This was a critical period, during which many characteristics of social complexity became institutionalized. One principal reason for this gap in our knowledge is that early remains lie under thick layers of later constructions, with the result that large areas of the Middle Preclassic levels at most lowland Maya sites are inaccessible to excavators. Since 2005, however, the members of the Ceibal-Petexbatun Archaeological Project have uncovered evidence of substantial construction activity in the early stages of human settlement at Ceibal. This was accomplished through deep vertical and extensive horizontal excavations and tunnels into Middle Preclassic contexts, focusing considerable attention on the origins and development of Maya civilization (Inomata et al. 2013, 2015). Our excavations recovered a total of 6,084 obsidian artifacts from unmixed Middle Preclassic contexts. This is the largest sample and earliest recovered to date from the Maya Lowlands.

\section{Obsidian Samples}

The lowland Maya city of Ceibal is the largest of all Pasión drainage sites, both in extent and in the total construction volume of its major public structures (Willey 1990). Extensive stratified excavations of the Ceibal-Petexbatun Archaeological Project have been carried out since 2005 in different parts of Ceibal, including two major groups of structures: Group A and Group D, as well as the nearby minor center of Caobal and other peripheral residential group locations. Obsidian artifacts were recovered throughout the city of Ceibal in archaeological contexts ranging from house mounds in the periphery to elite residences, burials, and dedicatory caches in the epicenter. The Ceibal-Petexbatun Archaeological Project has collected significantly more obsidian artifacts (Table 2) than the Ceibal Project of Harvard University $(N=1,331)$, primarily because we screened excavated soil through 


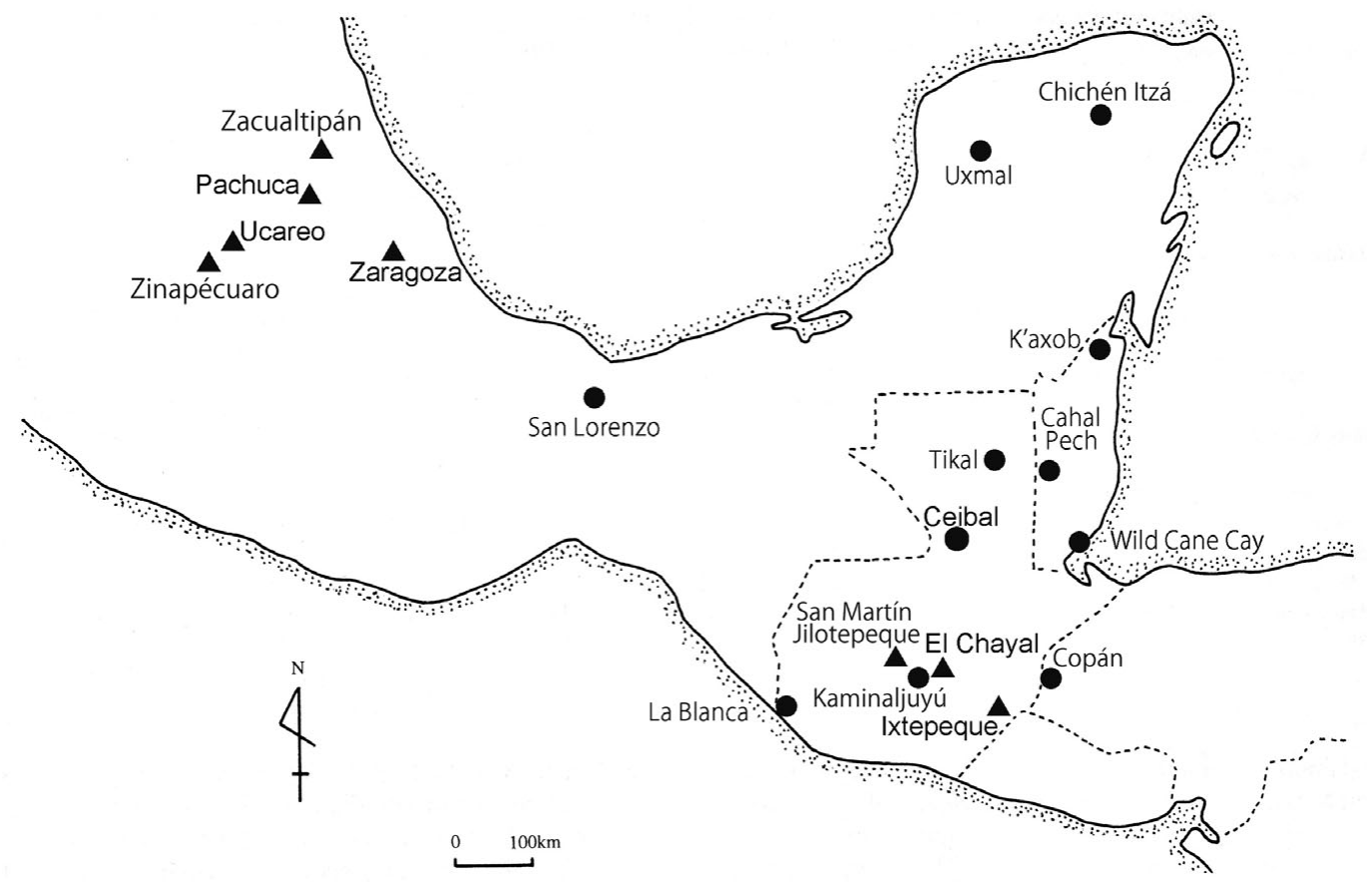

Figure 1. Map of Mesoamerica, showing the locations of Ceibal, other sites, and obsidian sources mentioned in the text.

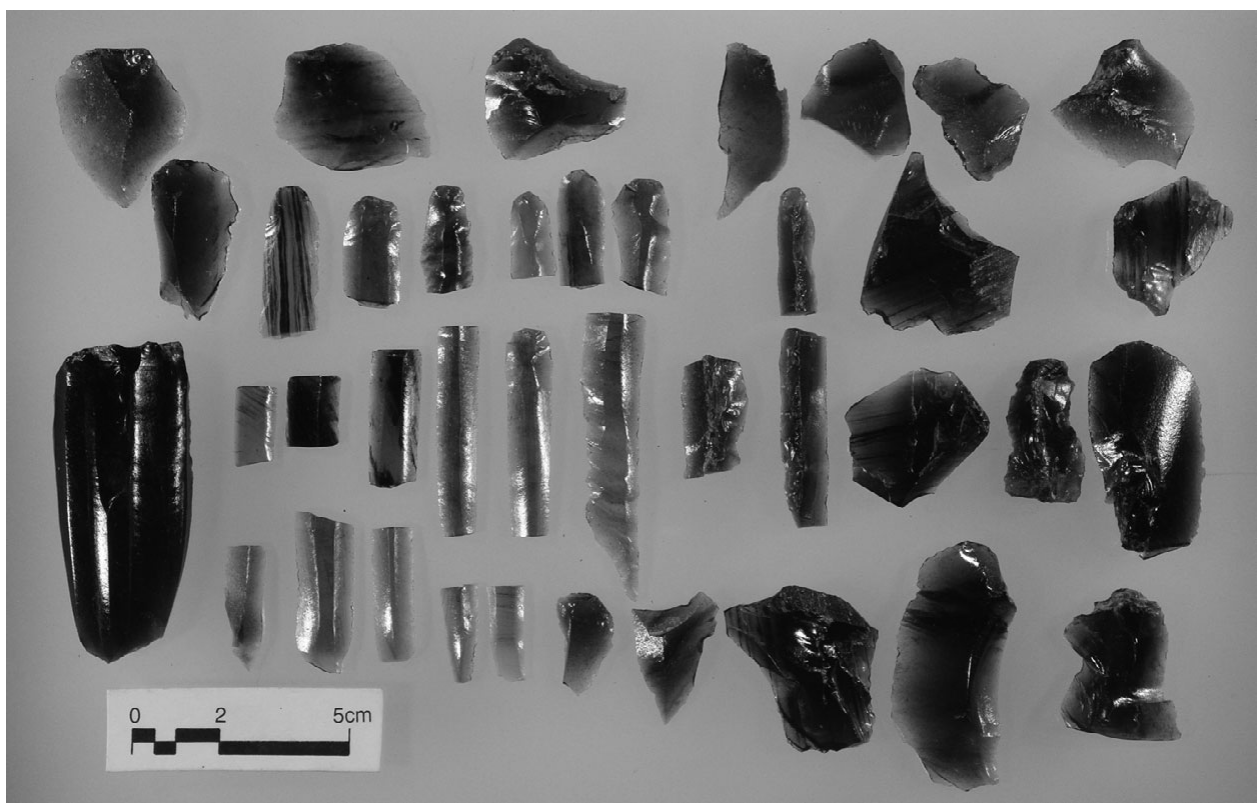

Figure 2. Obsidian artifacts from an unmixed Escoba 2 phase of the late Middle Preclassic midden deposit associated with an elite residence at Ceibal. 
Table 1. XRF Source Assignments of Obsidian Artifacts by Period from Ceibal, Guatemala.

\begin{tabular}{|c|c|c|c|c|c|c|c|c|c|c|}
\hline Period & SMJ & $\mathrm{ECH}$ & IXP & $\mathrm{PC}$ & $\mathrm{UC}$ & ZRG & ZNP & ZCL & UID & Total \\
\hline \multicolumn{11}{|c|}{ Real Phase, Early Middle Preclassic } \\
\hline Real 1 & 0 & 8 & 0 & 0 & 0 & 0 & 0 & 0 & 0 & 8 \\
\hline Real 2 & 5 & 40 & 0 & 0 & 0 & 0 & 0 & 0 & 0 & 45 \\
\hline Real 3 & 57 & 132 & 4 & 0 & 0 & 0 & 0 & 0 & 0 & 193 \\
\hline Real General & 0 & 3 & 0 & 0 & 0 & 0 & 0 & 0 & 0 & 3 \\
\hline Early Middle Preclassic total & 62 & 183 & 4 & 0 & 0 & 0 & 0 & 0 & 0 & 249 \\
\hline$\%$ & 24.9 & 73.5 & 1.6 & 0 & 0 & 0 & 0 & 0 & 0 & 100 \\
\hline \multicolumn{11}{|c|}{ Escoba Phase, Late Middle Preclassic } \\
\hline Escoba 1 & 142 & 43 & 0 & 0 & 0 & 0 & 0 & 0 & 0 & 185 \\
\hline Escoba 2 & 1,128 & 92 & 6 & 0 & 0 & 0 & 0 & 0 & 0 & 1,226 \\
\hline Escoba 3 & 636 & 99 & 5 & 0 & 0 & 0 & 0 & 0 & 0 & 740 \\
\hline Escoba General & 22 & 1 & 0 & 0 & 0 & 0 & 0 & 0 & 0 & 23 \\
\hline Late Middle Preclassic total & 1,928 & 235 & 11 & 0 & 0 & 0 & 0 & 0 & 0 & 2,174 \\
\hline$\%$ & 88.7 & 10.8 & 0.5 & 0 & 0 & 0 & 0 & 0 & 0 & 100 \\
\hline \multicolumn{11}{|l|}{ Cantutse Phase, Late Preclassic } \\
\hline Late Preclassic total & 225 & 41 & 0 & 0 & 0 & 0 & 0 & 0 & 0 & 266 \\
\hline$\%$ & 84.6 & 15.4 & 0 & 0 & 0 & 0 & 0 & 0 & 0 & 100 \\
\hline \multicolumn{11}{|l|}{ Xate Phase, Terminal Preclassic } \\
\hline Terminal Preclassic total & 148 & 76 & 2 & 0 & 0 & 0 & 0 & 0 & 0 & 226 \\
\hline$\%$ & 65.5 & 33.6 & 0.9 & 0 & 0 & 0 & 0 & 0 & 0 & 226 \\
\hline \multicolumn{11}{|l|}{ Junco Phase, Early Classic } \\
\hline Early Classic total & 1 & 34 & 7 & 0 & 0 & 0 & 0 & 0 & 0 & 42 \\
\hline$\%$ & 2.4 & 81 & 16.7 & 0 & 0 & 0 & 0 & 0 & 0 & 42 \\
\hline \multicolumn{11}{|l|}{ Tepeu Phase, Late Classic } \\
\hline Late Classic total & 7 & 83 & 3 & 0 & 0 & 0 & 0 & 0 & 0 & 93 \\
\hline$\%$ & 7.5 & 89.2 & 3.2 & 0 & 0 & 0 & 0 & 0 & 0 & 100 \\
\hline \multicolumn{11}{|l|}{ Bayal Phase, Terminal Classic } \\
\hline Terminal Classic total & 2 & 63 & 6 & 0 & 1 & 2 & 0 & 1 & 0 & 75 \\
\hline$\%$ & 2.7 & 84 & 8 & 0 & 1.3 & 2.7 & 0 & 1.3 & 0 & 100 \\
\hline Mixed contexts & 1,351 & 784 & 110 & 2 & 1 & 0 & 1 & 0 & 1 & 2,250 \\
\hline Total & 3,724 & 1,499 & 143 & 2 & 2 & 2 & 1 & 1 & 1 & 5,375 \\
\hline$\%$ & 69.3 & 27.9 & 2.7 & 0.04 & 0.04 & 0.04 & 0.02 & 0.02 & 0.02 & 100 \\
\hline
\end{tabular}

SMJ = San Martín Jilotepeque; ECH = El Chayal; IXP = Ixtepeque; PC = Pachuca; UC = Ucareo; ZRG = Zaragoza; $\mathrm{ZNP}=$ Zinapécuaro; $\mathrm{ZCL}=$ Zacualtipán; UID = Unidentified source.

$1 / 4$-inch mesh, unlike earlier field methodologies (Willey 1978).

In this study, I focus on diachronic changes of obsidian artifacts. For this reason, chronological control is of particular importance. Based on stratigraphic excavations, detailed ceramic analysis, and more than 150 radiocarbon dates, Takeshi Inomata refined the ceramic chronology of Ceibal (Inomata et al. 2015; Figure 3). All discussion of absolute chronology in this article is framed in terms of calibrated radiocarbon dates. To ensure temporal control, I eliminated obsidian artifacts that seemed to represent mixed time periods. Because no artifacts were recovered from unmixed Postclassic contexts, I do not discuss that time period. A total of 7,182 artifacts were recovered from temporally secure contexts pertaining to the Middle Preclassic through the Terminal Classic periods (1000 B.C.-A.D. 950). These serve as the basis for the diachronic discussions presented below. Temporally mixed samples were nevertheless considered only for the study of spatial distribution patterns of rare artifacts such as exhausted polyhedral cores and Mexican obsidian artifacts. Notably, the CeibalPetexbatun Archaeological Project has collected 6,914 obsidian artifacts from unmixed Preclassic contexts alone. The majority of Preclassic artifacts, 6,084 out of the 6,914, are from the Middle Preclassic. Many obsidian artifacts from 
Table 2. Visual and XRF Source Assignments of Obsidian Artifacts by Period from Ceibal, Guatemala.

\begin{tabular}{|c|c|c|c|c|c|c|c|c|c|c|}
\hline Period & SMJ & $\mathrm{ECH}$ & IXP & PC & $\mathrm{UC}$ & ZRG & ZNP & $\mathrm{ZCL}$ & UID & Total \\
\hline \multicolumn{11}{|c|}{ Real Phase, Early Middle Preclassic } \\
\hline Real 1 & 0 & 9 & 0 & 0 & 0 & 0 & 0 & 0 & 0 & 9 \\
\hline Real 2 & 7 & 51 & 0 & 0 & 0 & 0 & 0 & 0 & 0 & 58 \\
\hline Real 3 & 64 & 152 & 4 & 0 & 0 & 0 & 0 & 0 & 0 & 220 \\
\hline Real General & 0 & 3 & 0 & 0 & 0 & 0 & 0 & 0 & 0 & 3 \\
\hline Early Middle Preclassic total & 71 & 215 & 4 & 0 & 0 & 0 & 0 & 0 & 0 & 290 \\
\hline$\%$ & 24.5 & 74.1 & 1.4 & 0 & 0 & 0 & 0 & 0 & 0 & 100 \\
\hline \multicolumn{11}{|c|}{ Escoba Phase, Late Middle Preclassic } \\
\hline Escoba 1 & 253 & 48 & 0 & 0 & 0 & 0 & 0 & 0 & 0 & 301 \\
\hline Escoba 2 & 4,012 & 219 & 8 & 0 & 0 & 0 & 0 & 0 & 0 & 4,239 \\
\hline Escoba 3 & 1,094 & 109 & 5 & 0 & 0 & 0 & 0 & 0 & 0 & 1,208 \\
\hline Escoba General & 43 & 3 & 0 & 0 & 0 & 0 & 0 & 0 & 0 & 46 \\
\hline Late Middle Preclassic total & 5,402 & 379 & 13 & 0 & 0 & 0 & 0 & 0 & 0 & 5,794 \\
\hline$\%$ & 93.2 & 6.5 & 0.2 & 0 & 0 & 0 & 0 & 0 & 0 & 100 \\
\hline \multicolumn{11}{|l|}{ Cantutse Phase, Late Preclassic } \\
\hline Late Preclassic total & 466 & 46 & 0 & 0 & 0 & 0 & 0 & 0 & 0 & 512 \\
\hline$\%$ & 91 & 9 & 0 & 0 & 0 & 0 & 0 & 0 & 0 & 100 \\
\hline \multicolumn{11}{|l|}{ Xate Phase, Terminal Preclassic } \\
\hline Terminal Preclassic total & 227 & 89 & 2 & 0 & 0 & 0 & 0 & 0 & 0 & 318 \\
\hline$\%$ & 71.4 & 28 & 0.6 & 0 & 0 & 0 & 0 & 0 & 0 & 100 \\
\hline \multicolumn{11}{|l|}{ Junco Phase, Early Classic } \\
\hline Early Classic total & 5 & 51 & 8 & 0 & 0 & 0 & 0 & 0 & 0 & 64 \\
\hline$\%$ & 7.8 & 79.7 & 12.5 & 0 & 0 & 0 & 0 & 0 & 0 & 100 \\
\hline \multicolumn{11}{|l|}{ Tepeu Phase, Late Classic } \\
\hline Late Classic total & 6 & 107 & 6 & 0 & 0 & 0 & 0 & 0 & 0 & 119 \\
\hline$\%$ & 5 & 89.9 & 5 & 0 & 0 & 0 & 0 & 0 & 0 & 100 \\
\hline \multicolumn{11}{|l|}{ Bayal Phase, Terminal Classic } \\
\hline Terminal Classic total & 2 & 73 & 6 & 0 & 1 & 2 & 0 & 1 & 0 & 85 \\
\hline$\%$ & 2.4 & 85.9 & 7.1 & 0 & 1.2 & 2.4 & 0 & 1.2 & 0 & 100 \\
\hline Mixed contexts & 3,935 & 1,204 & 122 & 2 & 1 & 0 & 1 & 0 & 1 & 5,266 \\
\hline \multirow[t]{2}{*}{ Total } & 10,114 & 2,164 & 161 & 2 & 2 & 2 & 1 & 1 & 1 & 12,448 \\
\hline & 81.3 & 17.4 & 1.3 & 0.02 & 0.02 & 0.02 & 0.01 & 0.01 & 0.01 & 100 \\
\hline
\end{tabular}

later periods came from construction fills and were found mixed with earlier materials. Thus, considerably fewer obsidian artifacts dating to the Late Preclassic through Classic periods could be assigned to a single ceramic complex.

\section{Methodology and Results}

$p X R F$

I identified sources of obsidian artifacts by combining the pXRF analysis of a large sample of 5,375 obsidian artifacts and visual examination of the remaining 7,073 artifacts. The total sample of instrumental attributions is the largest such database published to date for any single site in the Maya area. A selected 43.2 percent sample $(N=5,375)$ was analyzed using an Olympus
Innov-X Delta Premium DP-6000-CC handheld $\mathrm{X}$-ray fluorescence analyzer. This flagship instrument combines a large-area, high-performance silicon drift detector (SDD), powerful 4W $\mathrm{X}$-ray rhodium anode tube, and $200 \mu \mathrm{A}$ current (max) plus optimized beam settings, providing faster measurements with accuracy than previous instruments. Prior to artifact analysis, I analyzed obsidian source samples taken from San Martín Jilotepeque, El Chayal, and Ixtepeque in highland Guatemala as well as Pachuca in highland Mexico using pXRF analysis. The obsidian calibration uses a set of very well characterized obsidian source samples in the MURR with data from previous NAA, XRF, and ICP measurements (Glascock and Ferguson 2012). The instrument was set to "geochem" 


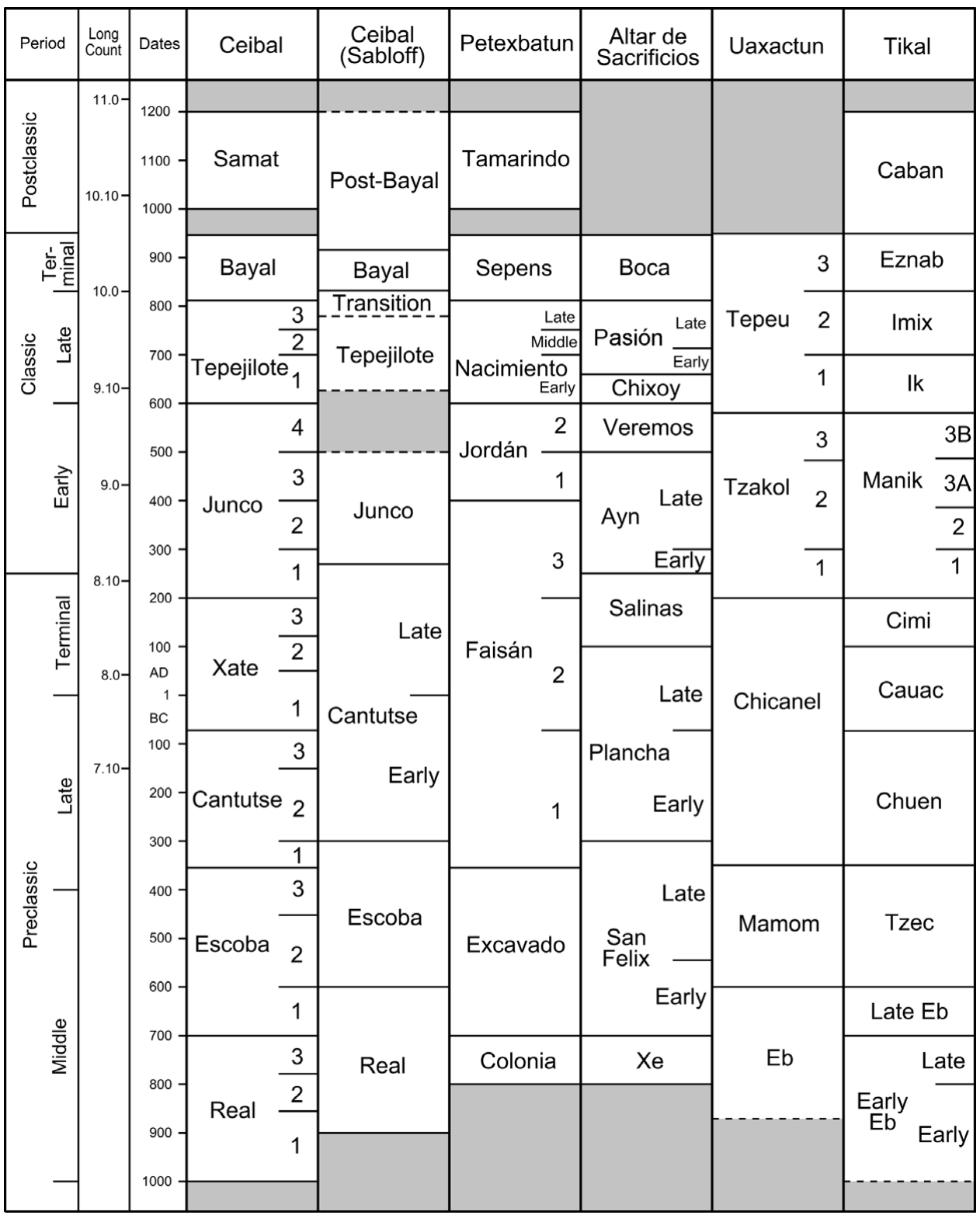

Figure 3. Ceramic chronologies of Ceibal and other regions of the Maya Lowlands (courtesy of Takeshi Inomata).

mode. All samples were counted for one minute to measure the minor and trace elements present. The elements measured include $\mathrm{K}, \mathrm{Ti}, \mathrm{Mn}$, $\mathrm{Fe}, \mathrm{Rb}, \mathrm{Sr}, \mathrm{Y}, \mathrm{Zr}, \mathrm{Nb}, \mathrm{Al}$, and $\mathrm{Si}$. The pXRF analysis was nondestructive. After data collection, element concentration data were tabulated in parts per million employing Microsoft Office Excel. By using bivariate plots to compare the artifact compositional data with data for sources in Guatemala and Mexico and for direct compar- ison of measured values, it was possible to determine sources for all of the artifacts except one (Table 1; Figures 4 and 5). I used a set of freely available statistical routines described in Gauss, originally formulated by Hector Neff and developed at MURR (http://archaeometry.missouri. edu/datasets/GAUSS_Download.html), to generate bivariate plots with confidence ellipses. Attributed sources discussed in the present study are not a representative sample of what was 


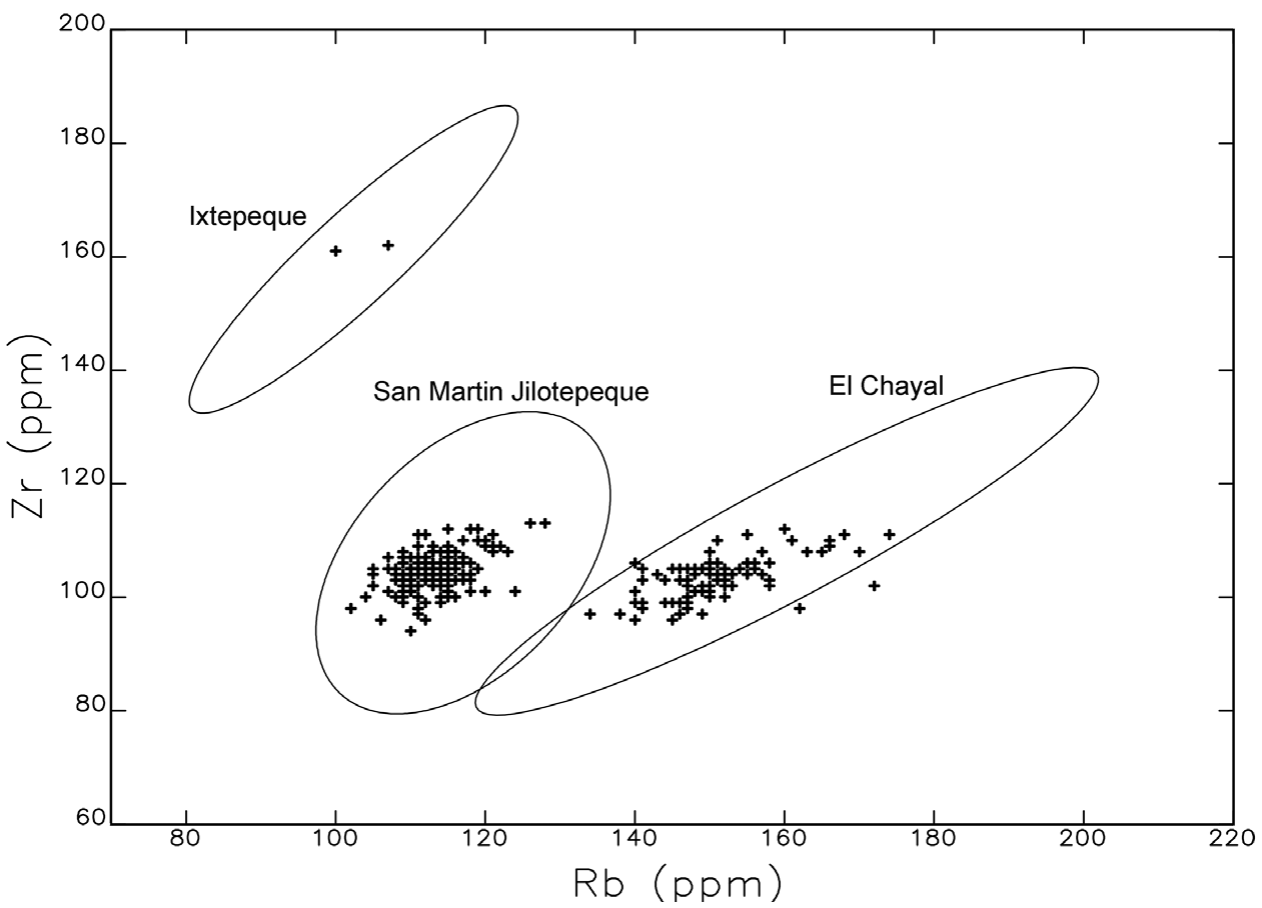

Figure 4. Bivariate plot of zirconium and rubidium comparing 90 percent confidence ellipses for obsidian sources with Terminal Preclassic obsidian artifacts from Ceibal measured by pXRF.

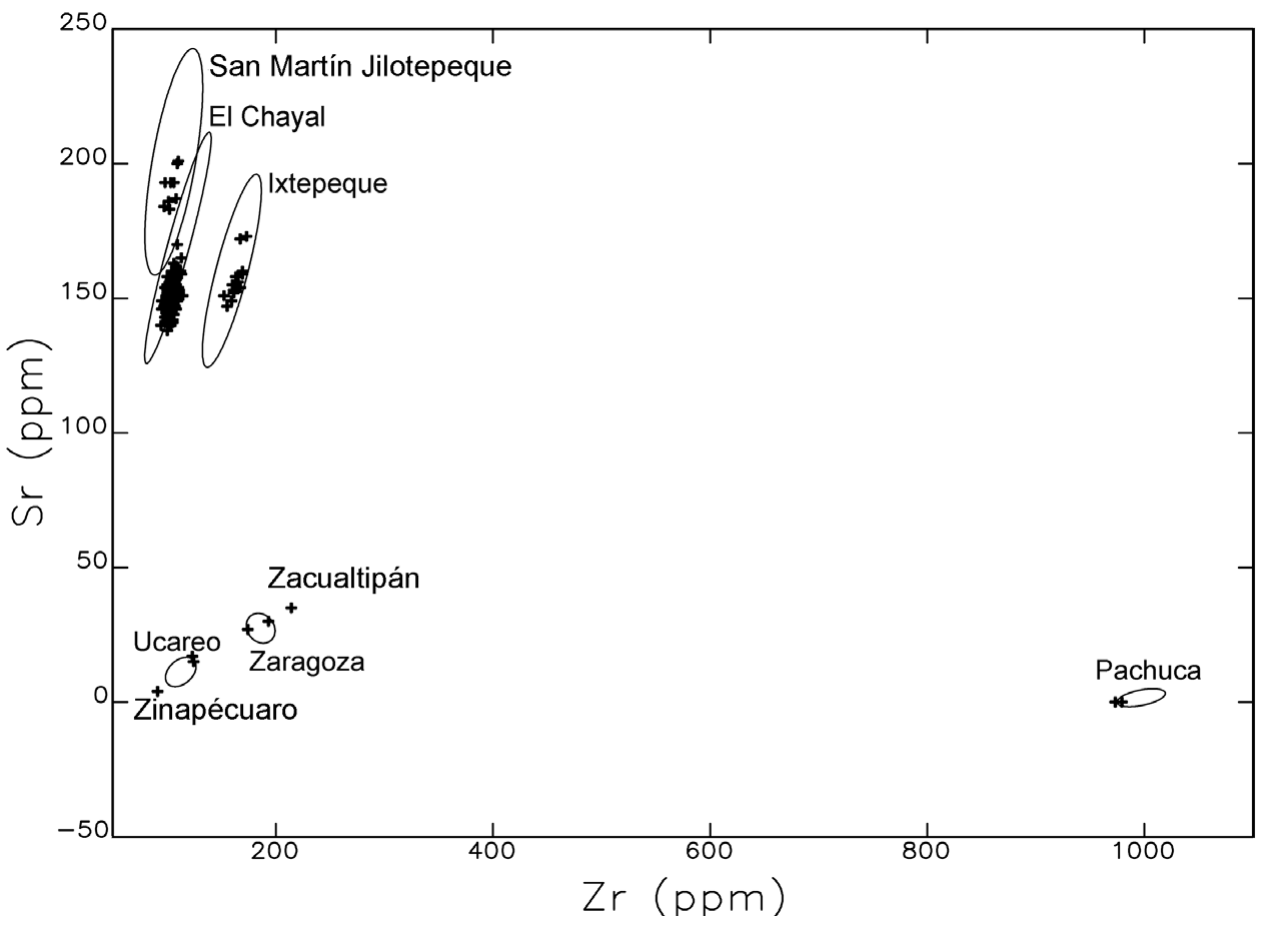

Figure 5. Bivariate plot of strontium and zirconium comparing 90 percent confidence ellipses for obsidian sources with Classic obsidian artifacts from Ceibal measured by pXRF. 
brought to Ceibal. Obsidian samples were not randomly selected for XRF analysis. Instead, all visually distinct obsidian artifacts were sampled, as were all pieces thought to be from a source other than San Martín Jilotepeque, which was the most common obsidian in the late Middle Preclassic, Late Preclassic, and Terminal Preclassic samples. This informed, nonrandom sampling strategy intentionally skewed the pXRF results toward high percentages of El Chayal and Ixtepeque obsidian; the point was to identify them all. Moreover, a greater proportion of rare artifacts, such as exhausted polyhedral cores and bifacial points, were intentionally selected for XRF analysis. Visual analysis was conducted to correct the sampling bias introduced by the informed, non-random sampling strategy of the pXRF analysis.

\section{Visual Analysis}

The accuracy of my visual analysis has been confirmed by a blind test of 100 obsidian artifacts from the La Entrada region of Honduras using NAA developed by Michael D. Glascock at the MURR. The results of the blind test indicated a 98 percent accuracy rate (Aoyama 1999:29). More importantly, independent scholars have demonstrated that, at least for certain collections of Maya obsidian artifacts that include the three major obsidian sources in highland Guatemala (El Chayal, San Martín Jilotepeque, and Ixtepeque), visual sourcing is both reproducible and accurate (Braswell et al. 2000). Nevertheless, visual analysis is not perfect science. I experienced some difficulty in determining the sources of certain obsidian artifacts from Ceibal. For example, the visual characteristics of some El Chayal obsidian with dusty inclusions are quite similar to San Martín Jilotepeque. Therefore, I first submitted a range of optically distinct artifacts to the pXRF for more secure definitive identification and thereafter used them as a comparative reference collection of known sources for further visual analysis. The reference collection also included geological specimens exhibiting the full range of optical variability of the precolumbian obsidian sources in Mexico, Guatemala, and Honduras. Future visual analysis will be complemented by petrographic analysis, because the presence and distribution of several compositions of microcrystals are responsible for the color and translucence of the obsidian (e.g., Pastrana 1987).

The combination of $\mathrm{pXRF}$ and visual analysis enabled source attribution of all obsidian artifacts at a high level of accuracy, precision, and reliability. Random samples have been demonstrated to sometimes underrepresent variation within heterogeneous populations, especially when there are limited numbers of atypical items, as is the case for Mexican obsidian artifacts (see Braswell 2011:123). Prior to the pXRF, I visually identified all eight Mexican obsidian artifacts from Ceibal; pXRF was not helpful in identifying any more. These extremely scarce artifacts are easily missed in any random sample. Nevertheless, I was not able to identify the sources of two of the eight artifacts through visual analysis alone. I was not familiar with two geological sources (Zacualtipán and Zinapécuaro), and artifacts from these sources could only be assigned through instrumental attribution. The bottom line is that visual analysis of large, statistically meaningful samples or, if possible, entire collections, allows a well-trained lithic analyst to study exchange networks more comprehensively than does chemical source analysis of small samples selected by inappropriate-including purely random-sampling methods. Daniel Pierce (2015) has recently demonstrated the utility of visual sourcing, even in an area of great variability such as West Mexico, where no fewer than 26 obsidian sources have been identified.

\section{Results}

Prehistoric political economies were a mix of many different resource mobilization strategies that crosscut the production, service, and distribution sectors (Hirth 1996). I reconstructed the precolumbian interregional and long-distance obsidian exchange system of Ceibal using a combination of pXRF, visual analysis, and technological analysis (see Aoyama 1999, 2009a). This allowed me to identify the sources of imported raw material and finished products (Table 3; Supplemental Tables 2-7). The ancient inhabitants of Ceibal imported obsidian from at least eight geological sources: San Martín Jilotepeque (81.3 percent; $N=10,114)$, El Chayal (17.3 percent; $N=2,164)$, and Ixtepeque (1.3 percent; $N=161)$ 
Table 3. Obsidian Sources by Technological Type of Obsidian Artifacts from Ceibal, Early Middle Preclassic Period.

\begin{tabular}{|c|c|c|c|c|c|c|c|c|}
\hline & \multirow{2}{*}{$\begin{array}{l}\text { Real } 1 \\
\text { ECH }\end{array}$} & \multicolumn{2}{|c|}{ Real 2} & \multicolumn{3}{|c|}{ Real 3} & \multirow{2}{*}{$\begin{array}{l}\text { Real General } \\
\text { ECH }\end{array}$} & \multirow[b]{2}{*}{ Total } \\
\hline & & $\mathrm{ECH}$ & SMJ & $\mathrm{ECH}$ & SMJ & IXP & & \\
\hline Small percussion blades & 0 & 1 & 0 & 9 & 2 & 0 & 0 & 12 \\
\hline Crested blades & 0 & 0 & 0 & 1 & 1 & 0 & 0 & 2 \\
\hline \multicolumn{9}{|l|}{ Initial pressure blades } \\
\hline Proximal segments & 0 & 0 & 1 & 3 & 6 & 0 & 0 & 10 \\
\hline Medial segments & 0 & 1 & 1 & 7 & 2 & 0 & 0 & 11 \\
\hline Distal segments & 0 & 0 & 0 & 1 & 0 & 0 & 0 & 1 \\
\hline \multicolumn{9}{|l|}{ Prismatic blades } \\
\hline Proximal segments & 0 & 1 & 1 & 17 & 7 & 0 & 0 & 26 \\
\hline Medial segments & 0 & 11 & 1 & 29 & 15 & 1 & 0 & 57 \\
\hline Distal segments & 0 & 1 & 0 & 6 & 1 & 0 & 1 & 9 \\
\hline Exhausted polyhedral cores & 0 & 0 & 0 & 2 & 0 & 0 & 0 & 2 \\
\hline Platform rejuvenation flakes & 0 & 0 & 0 & 0 & 1 & 0 & 0 & 1 \\
\hline Flakes from polyhedral cores & 0 & 0 & 0 & 0 & 1 & 0 & 0 & 1 \\
\hline Scrapers & 0 & 0 & 0 & 1 & 0 & 0 & 0 & 1 \\
\hline Denticulates & 0 & 0 & 0 & 1 & 0 & 1 & 0 & 2 \\
\hline Drills & 0 & 0 & 0 & 1 & 0 & 0 & 0 & 1 \\
\hline \multicolumn{9}{|l|}{ Large percussion flakes } \\
\hline Primary flakes & 0 & 0 & 0 & 2 & 0 & 0 & 0 & 2 \\
\hline Secondary flakes & 0 & 2 & 0 & 6 & 3 & 0 & 0 & 11 \\
\hline Tertiary flakes & 1 & 1 & 0 & 3 & 6 & 0 & 0 & 11 \\
\hline \multicolumn{9}{|l|}{ Small percussion flakes } \\
\hline Primary flakes & 1 & 5 & 0 & 7 & 2 & 0 & 0 & 15 \\
\hline Secondary flakes & 1 & 2 & 2 & 12 & 5 & 0 & 0 & 22 \\
\hline Tertiary flakes & 5 & 26 & 1 & 41 & 12 & 2 & 2 & 89 \\
\hline Chunks & 1 & 0 & 0 & 0 & 0 & 0 & 0 & 1 \\
\hline Flake cores & 0 & 0 & 0 & 3 & 0 & 0 & 0 & 3 \\
\hline Total & 9 & 51 & 7 & 152 & 64 & 4 & 3 & 290 \\
\hline$\%$ & 100 & 87.9 & 12.1 & 69.1 & 29.1 & 1.8 & 100 & \\
\hline
\end{tabular}

in highland Guatemala; Pachuca $(N=2)$ and Zacualtipán $(N=1)$ in the highland Mexican state of Hidalgo; Zaragoza, Puebla $(N=2)$; and Ucareo $(N=2)$ and Zinapécuaro $(N=$ 1 ), Michoacán (Figure 1; Table 2). This study provides a diachronic look at shifting obsidian procurement patterns, including interregional obsidian exchange from the Maya highlands to the lowlands and long-distance or trans-isthmian obsidian exchange from the Mexican highlands (Figure 6). El Chayal was the principal source of obsidian during the early Middle Preclassic and Classic periods, and San Martín Jilotepeque was heavily used in the late Middle Preclassic, Late Preclassic, and Terminal Preclassic periods. A small number of finished obsidian artifacts from highland Mexico were imported to Ceibal during the Classic period. In what follows, I present data related to the procurement and production of obsidian artifacts over time.

\section{Real Phase, Early Middle Preclassic Period}

The diachronic changes in obsidian procurement and production are summarized in Figure 7, which compares the percentage of pressure blades in obsidian artifacts with the percentage of artifacts containing remnant cortex over time in Ceibal. Very few obsidian artifacts dated to the early Middle Preclassic preMamom phase have been uncovered in the Maya Lowlands. A total of 290 obsidian artifacts were recovered from unmixed early Middle Preclassic pre-Mamom Real/Xe phase (1000700 B.C.) contexts. Pressure blades account for 39.3 percent $(N=114)$ of the total assemblage (Table 3 ). Although a previous model suggested that highland Guatemalan obsidian exchange commenced with major supplies from the San Martín Jilotepeque source during the Middle Preclassic period (e.g., Nelson 1985; Rice et al. 1985), the emerging picture is more complex. 


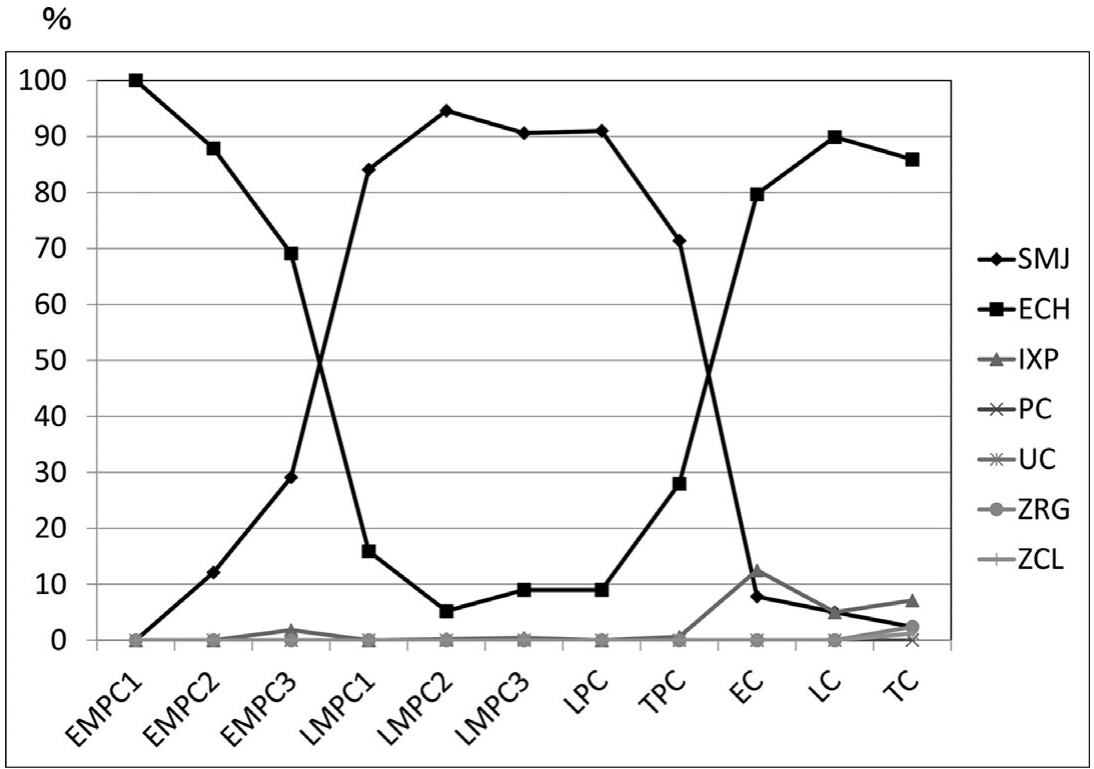

Figure 6. Frequencies of obsidian sources over time from Ceibal. SMJ = San Martín Jilotepeque; ECH = EI Chayal; IXP = Ixtepeque; PC = Pachuca; UC = Ucareo; ZRG = Zaragoza; ZNP = Zinapécuaro; ZCL = Zacualtipán; EMPC = early Middle Preclassic; $\mathbf{L M P C}=$ late Middle Preclassic; $\mathbf{L P C}=$ Late Preclassic; TPC = Terminal Preclassic; EC = Early Classic; $\mathbf{L C}=$ Late Classic; $\mathbf{T C}=$ Terminal Classic.

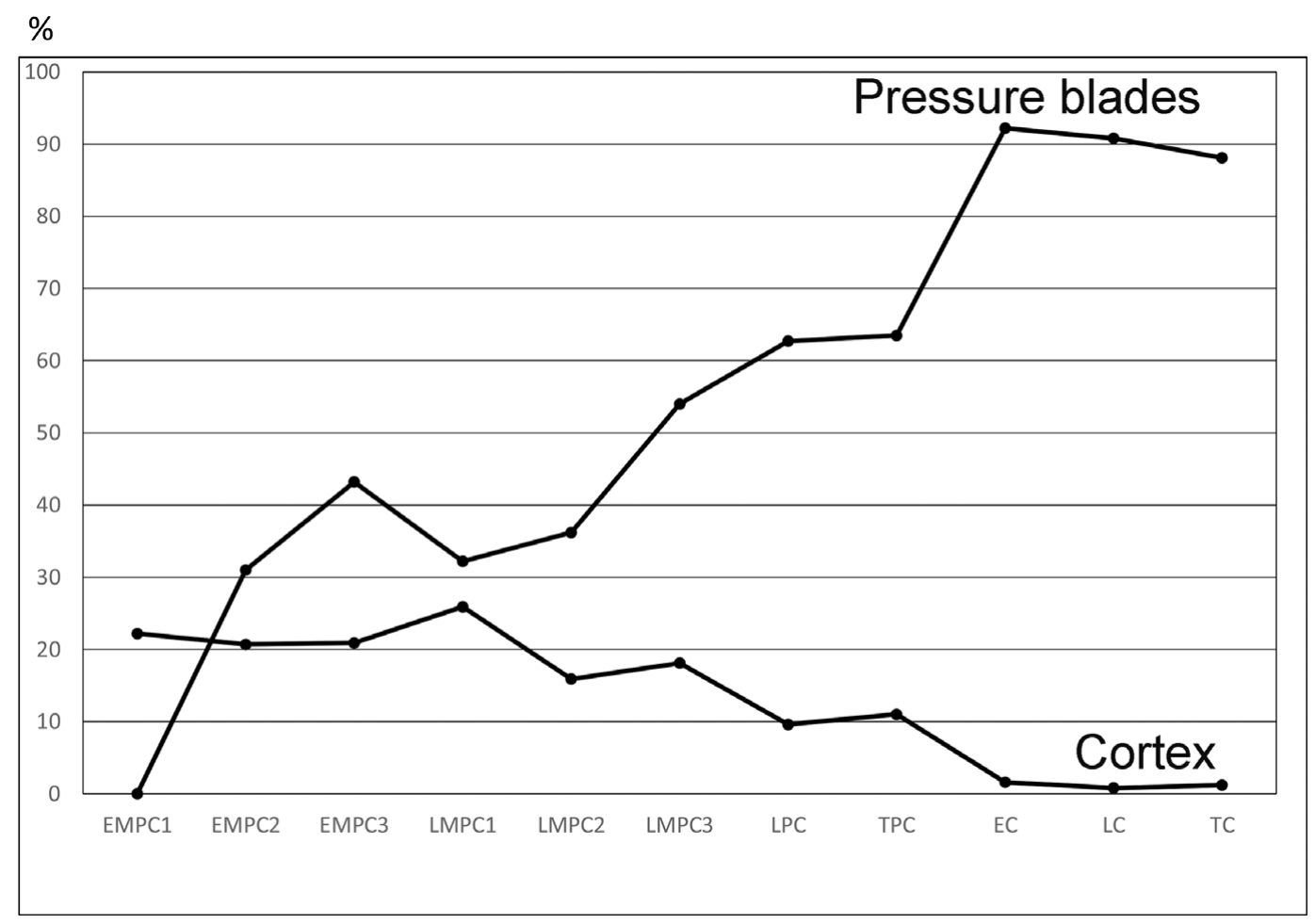

Figure 7. Diachronic change in the percentage of pressure blades in all obsidian artifacts comparing the percentage of artifacts containing remnant cortex over time in Ceibal. EMPC = early Middle Preclassic; LMPC = late Middle Preclassic; $\mathbf{L P C}=$ Late Preclassic; $\mathbf{T P C}=$ Terminal Preclassic; $\mathbf{E C}=$ Early Classic; $\mathbf{L C}=$ Late Classic; $\mathbf{T C}=$ Terminal Classic. 
The present study clearly indicates that El Chayal was the principal source for Ceibal during the early Middle Preclassic Real phase (Table 2; Figure 6). By way of comparison, nearly all the obsidian from the Early Preclassic through the Early Postclassic period came to Copán, Honduras, from Ixtepeque (Aoyama 2001:348). Thus, long-time differences in procurement patterns (east vs. west of the Maya Lowlands) already existed in Pre-Mamom times.

The Real phase, which has three subphases, was a critical period of sociopolitical development at Ceibal. At the beginning of the Real 1 phase (1000-850 B.C.), a formal ceremonial center with a public plaza was founded at Ceibal (Inomata et al. 2013:467). The plaza was delimited by a square structure (Structure Ajaw) to the west and a long platform (Structure Xa'an) to the east, which constitutes the earliest known example of a so-called E-Group assemblage in the Maya Lowlands. In spite of our extensive stratified excavations, only nine obsidian artifacts were recovered from the Real 1 layers (Table 3). Obsidian is quite rare in human occupation layers dating to this time period. All artifacts were manufactured from El Chayal obsidian. During the Real 1 phase, El Chayal obsidian was imported to Ceibal in the form of nodules for the production of percussion flakes. This observation is based on the presence of flake cores and flakes, the high percentage of cortex found on El Chayal obsidian artifacts (22.2 percent; $N=2$ ), and the absence of blades. Primary flakes have a remnant cortex on more than 50 percent of the dorsal surfaces, while secondary flakes show less than 50 percent. Tertiary flakes are those showing no remnant cortex. Similarly, Awe and Healy (1994) report 28 obsidian flakes and note the absence of obsidian blades at Cahal Pech, Belize, during the first half of the early Middle Preclassic period (1000 850 B.C.). Small quantities of prismatic blades made from Ixtepeque obsidian were imported to Copán as finished products, while Ixtepeque obsidian was imported mainly as nodules for the production of percussion flakes during the first half of the early Middle Preclassic Gordon phase (1000-850 B.C.; Aoyama 1999:Table 2).

During the Early and Middle Preclassic period, the expedient flake technology also predominated in other regions of Mesoamerica, including the Basin of Mexico (Boksenbaum et al. 1987), the Oaxaca Valley (Parry 1987), San Lorenzo (Coe and Diehl 1980), the central depression and Pacific coast of Chiapas (Clark and Lee 1984), and the Pacific coast of Guatemala (Aoyama 2004; Jackson and Love 1991). El Chayal obsidian was transported over greater distances and in larger quantities than either San Martín Jilotepeque or Ixtepeque obsidian during the Early Preclassic period (e.g., Cobean et al. 1971; Golitko and Feinman 2015; Pires-Ferreira 1975; Zeitlin 1982). While Guadalupe Victoria, Puebla, was the primary source of obsidian for the inhabitants of San Lorenzo, El Chayal was the most common source of Guatemalan obsidian at San Lorenzo between the Ojochi phase (1800-1600 B.C.) and the Palangana phase (800-400 B.C.; Cobean et al. 1971, 1991; Hirth et al. 2013). In the central depression of Chiapas, the inhabitants imported obsidian spalls for the production of percussion flakes from several sources, such as San Martín Jilotepeque, El Chayal, and Tajumulco during the Early Preclassic period (Clark and Lee 2007). Prismatic blades of El Chayal obsidian were imported in finished form at most sites in the Pacific Chiapas and Guatemala regions during the Middle Preclassic period, although expedient flake production persisted after the introduction of prismatic blades (Rosenswig 2010). As in Ceibal during the Real phase, El Chayal was the most common source for obsidian at the Pacific coast center of La Blanca during the Conchas phase (1000-600 B.C.; Jackson and Love 1991). In sum, the inhabitants of Ceibal and those of neighboring centers in the Tehuantepec Isthmian region, which included the central depression of Chiapas, the Pacific Chiapas and Guatemala regions, and the southern Gulf Coast, shared the expedient flake technology and participated in the El Chayal obsidian exchange networks during the Real 1 phase.

During the Real 2 phase (850-775 B.C.), the Ceibal E-Group assemblage grew to be the earliest known plaza-pyramid complex in the Maya Lowlands (Inomata et al. 2013:468). There is no clear evidence of local blade production due to the lack of exhausted polyhedral cores or other manufacturing debris (Table 3). Obsidian 
blades may have been imported in finished form to Ceibal during the Real 2 phase. Nevertheless, many hundreds of pressure blades can be made from a polyhedral core. Given the number of obsidian artifacts related to core-blade production, including a small percussion blade as well as initial and later series pressure blades, pressure blades may have been manufactured locally during this phase. On the basis of the low percentage of pressure blades (31 percent; $N=$ 18), which include initial pressure and later series pressure blades (prismatic blades) and the high percentage of percussion flakes (67.2 percent; $N$ = 39) and cortex in the obsidian artifacts (20.7 percent; $N=12$ ), it can be hypothesized that expedient flake production persisted after the introduction of pressure blades. Of the recovered obsidian artifacts from the Real 2 layers $(N=58)$, El Chayal was the dominant source of obsidian (87.9 percent; $N=51$ ), with minor quantities of obsidian from San Martín Jilotepeque (12.1 percent; $N=7$ ).

In the Real 3 phase (775-700 B.C.) there is unambiguous evidence of local production of pressure blades. The importation of large polyhedral cores of El Chayal and San Martín Jilotepeque obsidian to Ceibal and the local production of pressure blades began after the rise of political complexity at Ceibal. Therefore, we cannot say that blade specialization caused that development. Of the 220 obsidian artifacts dated to the Real 3 phase, El Chayal (69.1 percent, $N=152$ ) continued to be the most common source, followed by San Martín Jilotepeque (29.1 percent, $N=64$ ); for the first time, Ixtepeque obsidian appears in the Ceibal obsidian sample (1.8 percent, $N=4$ ). The presence of exhausted polyhedral cores and artifacts related to the percussion stage of core-blade production, such as small percussion and crested blades, suggest that large polyhedral cores of El Chayal obsidian were imported to Ceibal and that pressure blades were manufactured locally during the Real 3 phase (Table 3). From Real 3 times onward, blade makers in Ceibal created crested ridges to remove crested blades. A portion of the El Chayal obsidian was imported to Ceibal in the form of nodules for the production of percussion flakes. This conclusion is based on the presence of flake cores, the high percentage of cortex found on $\mathrm{El}$
Chayal obsidian artifacts (22.4 percent; $N=34$ ), and a relatively low percentage of pressure blades (41.4 percent; $N=63$ ) made from El Chayal obsidian.

Although no exhausted polyhedral cores of San Martín Jilotepeque obsidian were recovered from Real 3 phase levels, artifacts related to the percussion stage of core-blade production were collected. These include small percussion blades, a crested blade, a platform rejuvenation flake, and a flake from a polyhedral core made of San Martín Jilotepeque obsidian. Together, these indicate the local production of pressure blades. Moreover, it is likely that a portion of the San Martín Jilotepeque obsidian was imported to Ceibal in the form of nodules, based on the relatively high percentage of percussion flakes (43.8 percent; $N=28$ ) and the high percentage of cortex found on San Martín Jilotepeque obsidian artifacts (18.8 percent; $N=12$ ).

In sum, the obsidian artifacts from Real 3 phase Ceibal present the earliest known unambiguous evidence of local production of prismatic blades made from both sources of obsidian (El Chayal and San Martín Jilotepeque) in the Maya Lowlands. Ceibal society appears to have attained at least the minimal level of sociopolitical complexity necessary for the procurement of large polyhedral cores of obsidian and the local production of pressure blades. In contrast, from the inception of its importation to K'axob, Belize, during the early part of the Middle Preclassic period (800-600 B.C.), obsidian arrived as finished prismatic blades (McAnany 2004:308). At Tikal, Guatemala, Moholy-Nagy (2003:Tables 3.24 and 3.29) identified three obsidian prismatic blades and two small flakes that dated to the early Middle Preclassic $\mathrm{Eb}$ phase (800-600 B.C.), although there is no clear evidence of local blade production.

\section{Late Middle Preclassic, Late Preclassic, and Terminal Preclassic Periods}

Pyramid building and refurbishing continued, and the local population increased steadily during the late Middle Preclassic Escoba phase (700-350 B.C.) at Ceibal (Inomata et al. 2015:4269; Willey 1990:239). Our extensive stratified excavations in unmixed late Middle 
Preclassic deposits yielded the largest sample of obsidian artifacts $(N=5,794)$ at Ceibal of any time period of human occupation. The percentage of obsidian artifacts (29.9 percent) among all chipped stone artifacts $(N=$ 19,397) during the late Middle Preclassic period increased substantially from the early Middle Preclassic period (2.9 percent; 290/10,047). Thus, there is a significant increase in the relative quantity of obsidian imported at this time. San Martín Jilotepeque (93.2 percent; $N=5,402$ ) accounted for most of the obsidian brought to Ceibal, while minor quantities were procured from El Chayal (6.5 percent; $N=379)$ and Ixtepeque ( 0.2 percent; $N=13)$. One possible interpretation for this drastic change in obsidian exchange is provided by Geoffrey Braswell (2010:133). During the second half of the Middle Preclassic period, a bounded network system emerged at the Preclassic center of Kaminaljuyú near El Chayal, resulting in a concomitant decrease in the circulation of the El Chayal obsidian in the Maya Lowlands. In contrast, due to the simpler open network system of the Preclassic eastern Kaqchikel region, where San Martín Jilotepeque is located, obsidian from this source could circulate throughout the Maya area.

As in the Real 3 phase, obsidian was imported in the form of large polyhedral cores that were modified into percussion and pressure blades during the late Middle Preclassic period. This interpretation is based on the presence of exhausted polyhedral cores and artifacts related to the percussion stage of core-blade production. The latter include macroblades, small percussion blades, crested blades, and a wide variety of core rejuvenation flakes (Supplemental Table 2). Exhausted polyhedral cores from San Martín Jilotepeque and El Chayal that were recovered from late Middle Preclassic unmixed contexts indicate local production of pressure blades. Exhausted polyhedral cores from Ixtepeque from late Middle Preclassic secondary contexts mixed with earlier materials also indicate local blade production. The relatively high percentage of cortex (16.9 percent; $N=978$ ) found on the obsidian artifacts dating to the late Middle Preclassic, a comparatively low percentage of pressure blades (40 percent; $N=2,319$ ), and abundant flake cores all suggest that obsidian nodules also were brought to the site for the production of percussion flakes (Figure 7).

The relative frequency of obsidian to all chipped-stone artifacts is significantly greater in central Ceibal than at the nearby minor center of Caobal and other peripheral sites, suggesting that the inhabitants of the epicenter of Ceibal had greater access to obsidian imports than did the peripheral areas (Aoyama and Munson 2012). In contrast to the high percentage of cortex found on obsidian artifacts from Ceibal, virtually no obsidian artifacts at Caobal have cortex for any time in the precolumbian sequence. It is possible that Ceibal elites distributed finished blades, as well as already trimmed and partially reduced polyhedral cores, outside of the site center during the Preclassic and Classic periods.

During the Late Preclassic period (350-75 B.C.) Ceibal became a city, reaching its first peak population of about 10,000 people (Willey 1990:241). Due to the Maya penchant for building directly on top of earlier structures, fewer obsidian artifacts from unmixed Late Preclassic deposits were found in Ceibal compared to the late Middle Preclassic deposits (Supplemental Table 3). San Martín Jilotepeque continued to be the most common source for obsidian (91 percent; $N=466$ ), followed by El Chayal ( 9 percent; $N=46$ ). No Ixtepeque obsidian artifacts were found from unmixed Late Preclassic contexts, and only four were recovered from secondary contexts.

In comparison to the late Middle Preclassic period, pressure blades account for a greater percentage of all obsidian artifacts during the Late Preclassic period (62.7 percent; $N=321$ ). Given this higher percentage as well as the lower frequency of cortex (9.6 percent; $N=49$ ), it appears that obsidian was imported to Ceibal mainly as large polyhedral cores (Figure 7). A small portion of the obsidian was brought to the site in the form of nodules, based on the presence of flake cores and numerous flakes.

The relative frequency of pressure blades (63.5 percent; $N=202$ ) during the Terminal Preclassic period (75 B.C.-A.D. 200) increased slightly from the Late Preclassic period. The presence of exhausted polyhedral cores and percussion blades, such as small percussion blades and crested blades, suggests that large 
polyhedral cores were imported to Ceibal during the Terminal Preclassic period (Supplemental Table 4). Moreover, a flake core and the relatively high percentage of cortex found on obsidian artifacts ( 11 percent; $N=35$ ) imply that a portion of the obsidian was imported to Ceibal in the form of nodules in the Terminal Preclassic period. The primary source of obsidian was San Martín Jilotepeque (71.4 percent; $N=227$ ), followed by El Chayal obsidian (28 percent; $N=89$ ). Minor quantities of obsidian were brought from Ixtepeque ( 0.6 percent; $N=2$ ).

\section{Classic Period (A.D. 200-950)}

The ruler K'an Mo' Bahlam (ca. A.D. 415) is mentioned in a retrospective text on the Late Classic Hieroglyphic Stairway of Ceibal, but Ceibal was occupied in only a very minor way during the latter part of the Early Classic period (A.D. 450-600; Inomata 2012; Sabloff 1975). Unmixed Early Classic (A.D. 200-600) deposits in Ceibal contained only 64 obsidian artifacts, supporting the conclusion that population declined during this time. As shown in Figure 6 and Supplemental Table 5, during the Early Classic period, El Chayal once more became the major source of obsidian artifacts in Ceibal (79.7 percent; $N=51$ ), followed by Ixtepeque (12.5 percent; $N=8$ ). Only a small amount of obsidian was from San Martín Jilotepeque (7.8 percent; $N=5)$. In fact, San Martín Jilotepeque obsidian appears in significantly lower quantities in all contexts dating to the Classic period than in Preclassic deposits. In contrast, greater quantities of Ixtepeque obsidian were imported to Ceibal throughout the Classic period than in Preclassic times.

Previous studies have demonstrated the predominance of El Chayal obsidian in many other parts of the Maya Lowlands during the Classic period (e.g., Braswell 2011; Brown et al. 2004; Healy et al. 1984; Moholy-Nagy et al. 2013; Nelson 1985; Rice et al. 1985). One of the reasons for the dramatic increase in the exchange of El Chayal obsidian may have to do with the decline of the Kaminaljuyú polity around A.D. 150 (Inomata et al. 2014:401). I argue that the bounded network system of the
Preclassic Kaminaljuyú broke down, resulting in a concomitant open network system that made it possible for obsidian from El Chayal to be circulated throughout the Maya Lowlands. In fact, from the Xate 2 phase (A.D. 50-125) to the Xate 3 phase (A.D. 125-200) of Terminal Preclassic Ceibal, El Chayal increased from one quarter (43/179) to nearly half (46 percent; 28/61) of the sample, while the percentage of San Martín Jilotepeque decreased from three quarters (134/179) to half (33/61). Moreover, Braswell (2010:133) argues that very simple hierarchical settlement and extended distribution systems persisted in the eastern Kaqchikel highland until the beginning of the Early Classic period. These political changes near two major obsidian sources in the Maya highlands during the Preclassic to Classic transition must have greatly affected the circulation of the obsidian in the Maya Lowlands.

Based on the considerably lower percentage of cortex found on obsidian artifacts from Early Classic contexts (1.6 percent; $N=1$ ) compared to the Terminal Preclassic period (11 percent; $N=35$ ), it can be concluded that obsidian was imported primarily in the form of more prepared polyhedral cores that were transformed into pressure blades at Ceibal. This inference is also supported by the significantly greater percentage of pressure blades (92.2 percent; $N$ = 59) in Early Classic than in the Terminal Preclassic deposits (63.5 percent; $N=202$ ). This pattern, in which El Chayal obsidian was imported in the form of more highly prepared polyhedral cores throughout the Classic period is also evident at the neighboring site of Aguateca (Aoyama 2009a) and many other Petén sites (e.g., Aoyama and Laporte 2009). Macroblades and crested blades, which were related to the percussion stage of core-blade production, are notably absent from the Classic contexts of Ceibal, as are small percussion blades (Supplemental Tables 5-7). Moreover, virtually no obsidian artifacts have cortex (Figure 7). As in earlier periods, pressure blades were the most common form of obsidian artifact. Microwear and contextual analyses indicate that pressure blades made of highland Guatemalan obsidian were mainly valued as utilitarian goods. Both elites and commoners used them for a 
wide variety of craft production and domestic tasks.

\section{Mexican Obsidian Artifacts in Ceibal}

A small number of finished artifacts (primarily prismatic blades, but also small quantities of bifacial points) from highland Mexico were imported to Ceibal during the Classic period. Their restricted spatial distribution indicates that Mexican obsidian tools may have been designated as elite goods. These artifacts are concentrated in two major groups of structures in the central part of Ceibal, Groups A and D, which consist of public structures and plazas covering an area of about $1 \mathrm{~km}^{2}$. In contrast, Mexican obsidian is completely absent in peripheral areas. The use or display of such small quantities of long-distance exchange goods appears to have been primarily of social and symbolic rather than economic importance. They may have arrived at Ceibal as elite gifts (e.g., Spence 1996).

A medial fragment of a bifacial point made of green obsidian from the Pachuca, Hidalgo, source was found in an Early Classic secondary deposit in Structure A-2, a large platform. So far, this is the only green obsidian bifacial point found at Ceibal. A proximal segment of a prismatic blade made of Pachuca obsidian was found in the E-Group of Group A and a fragment of a bifacial point made of Zinapécuaro, Michoacán, obsidian was recovered from the massive A24 platform. These two artifacts date to the Late Classic period. The paucity of Mexican obsidian-even in the central groups of Ceibalduring the Early and Late Classic periods may be related to the reduced population of this period and the subordinate nature of the elites residing at the site during those centuries.

A total of five Mexican obsidian artifacts were recovered from Terminal Classic contexts. Four artifacts are from Group D: (1) a proximal segment of a prismatic blade from the East Plaza made of obsidian from Zaragoza, Puebla; (2) a fragment of a bifacial point from the West Plaza, also made of Zaragoza obsidian; (3) a medial segment of a prismatic blade made of Zacualtipán, Hidalgo, obsidian; and (4) a medial segment of a prismatic blade made of Ucareo, Michoacán, obsidian. Another medial segment of a prismatic blade made of Ucareo obsidian was excavated in the E-Group plaza of Group A. The notable absence of green obsidian artifacts and the overall scarcity of Mexican obsidian artifacts at Terminal Classic Ceibal indicate that elites may not have participated in developing longdistance obsidian exchange networks during the tenth century (e.g., Braswell 2010:137). The presence of Mexican obsidian is a sensitive chronological indicator for the Early Classic, Terminal Classic, and Early Postclassic periods in the nearby Punta de Chimino in the Petexbatun region, the southeast and central-western Petén region (Aoyama 2006, 2009b; Aoyama and Laporte 2009), western Honduras, and especially the northern Maya Lowlands (Aoyama 2001; Braswell 2003).

\section{Obsidian Exchange and the Fall of the Ceibal Dynasty}

Compared to the open network system centered on Classic El Chayal, there was a very sharp delineation of exchange covers $60 \mathrm{~km}$ northeast of Copan in the La Entrada region. This region had access to polyhedral cores of Ixtepeque obsidian. Sites in the northern extremity of the La Entrada region, by contrast, received most of their obsidian from the San Luis source, $30 \mathrm{~km}$ to the east in Honduras (Aoyama 1999:143). This sharp decrease in Ixtepeque obsidian suggests a bounded network system in the Classic Copán state. After the demise of centralized authority in Copán during the ninth century, the bounded network system of the Classic Copán state broke down and the Ixtepeque obsidian exchange sphere began to expand, particularly along the Caribbean coast. For example, Ixtepeque obsidian was more prevalent than El Chayal at Wild Cane Cay, Belize, during the Postclassic period (McKillop 1996).

The notable presence of Mexican obsidian artifacts at Chichén Itzá, Uxmal, and other sites in northern Maya Lowlands (Braswell 2010:137), as well as smaller coastal sites (McKillop 1996:57), implies that their distribution became more widespread and decentralized during the tenth century. Although Ixtepeque was still the most commonly used obsidian source, even the inhabitants of a small village in Copán imported 
finished prismatic blades from Pachuca and Ucareo sources during the Early Postclassic Ejar phase (A.D. 950-1050; Aoyama 2001:356). The inhabitants of the Terminal Classic city of Ceibal did not. Moreover, all proximal segments of prismatic blades made of El Chayal obsidian from Terminal Classic Ceibal have scratched platforms, but none of them have pecked-andground platforms, which became common after about AD 900 (see Braswell 2011:126). In summary, the prevalence of El Chayal obsidian rather than Ixtepeque obsidian, and the scarcity of Mexican obsidian artifacts at Terminal Classic Ceibal, imply that the fall of the Ceibal dynasty may have occurred shortly after A.D. 889, the last date recorded on Ceibal stone monuments.

\section{Summary and Conclusions}

The results of the present study suggest that El Chayal obsidian was heavily used during the early Middle Preclassic period and that San Martín Jilotepeque was the principal source of obsidian in the late Middle Preclassic, Late Preclassic, and Terminal Preclassic periods. El Chayal once again became the major source for Ceibal during the Classic period. The dramatic decrease in use of El Chayal obsidian during the late Middle Preclassic period, at Ceibal and in many other part of the Maya Lowlands, may have to do with the emergence of a bounded network system at Kaminaljuyú during the late Middle Preclassic. This system broke down during the Terminal Preclassic collapse, resulting in a striking increase in El Chayal during the Early Classic period.

The interregional exchange of large polyhedral cores of obsidian from the Maya highlands, and the local production of pressure blades, began after the rise of political complexity at Ceibal, which occurred by the early Middle Preclassic Real 3 phase. Early leaders of Ceibal may have sponsored the procurement of large polyhedral cores of obsidian along with local production of fine blades on behalf of their community as a means of consolidating and legitimizing their own political authority. The Ceibal data present the earliest known evidence for the local production of pressure blades made from each source of obsidian (El Chayal and San Martín Jilotepeque).

The procurement of large polyhedral cores of obsidian from the Maya highlands increased from the Real 3 phase to the Terminal Preclassic period. Obsidian was also imported to Ceibal in the form of nodules for the production of percussion flakes during the Preclassic period. In contrast, material was imported mainly in the form of more prepared polyhedral cores, which were transformed into pressure blades at Ceibal, throughout the Classic period. Ceibal elites may have distributed finished blades and semi-exhausted polyhedral cores of highland Guatemalan obsidian outside of the site center throughout the Preclassic and Classic periods. Long-distance exchange of very small quantities of finished obsidian artifacts from highland Mexico was primarily of social and symbolic rather than economic importance. In conclusion, interregional exchange of obsidian from the Maya highlands was of great economic significance to the inhabitants of the community, and was more crucial to the development of lowland Maya civilization than was long-distance exchange with Mexico.

Acknowledgments. Funding for my research in Guatemala (2005-2017) has been provided by the Ministry of Education, Culture, Sports, Science, and Technology-Japan (Grants-inAid for Scientific Research No. 21101001, No. 21101003, No. 26101001, and No. 26101003) and the Japan Society for the Promotion of Science (Grants-in-Aid for Scientific Research No. 17401024, No. 21402008, and No. 26300025). Michael D. Glascock kindly provided me with the database for all obsidian source samples in Guatemala, Honduras, and Mexico analyzed by pXRF at the University of Missouri Research Reactor. Mark Golitko kindly offered me the database for the Tikal obsidian artifacts analyzed by pXRF at the Field Museum of Natural History. Hattula Moholy-Nagy, Hector Neff, and Geoffrey Braswell helped me with solid advice in order for me to start to analyze Ceibal obsidian artifacts by pXRF. This paper benefited considerably from thoughtful suggestions of three anonymous reviewers. I thank other members of the Ceibal-Petexbatun Archaeological Project, particularly Takeshi Inomata, Daniela Triadan, Ottó Roman, Víctor Castillo, Juan Manuel Palomo, Flory Pinzón, and Estela Pinto, for their guidance and support during the lithic analysis. Joyce Cunningham kindly helped me to edit the manuscript. I also thank Geoffrey Braswell and Sowparnika Balaswaminathan for their outstanding editorial work. My wife, Vilma Aoyama, helped me with the Spanish abstract. Any errors remain entirely my responsibility. 
Data Availability Statement. Data on the weight of obsidian artifacts by period and data on the obsidian sources by technological type of obsidian artifacts from the late Middle Preclassic period to the Terminal Classic period used in this study are published online in Supplemental Tables 1-7.

Supplemental Materials. Supplemental materials are linked to the online version of this paper, which is accessible via the SAA member login at https://doi.org/10.1017/laq.2017.2. These include the following tables:

Supplemental Table 1. Weight (g) of obsidian artifacts by visual and XRF source assignments by period from Ceibal, Guatemala.

Supplemental Table 2. Obsidian sources by technological type of obsidian artifacts from Ceibal, Late Middle Preclassic period.

Supplemental Table 3. Obsidian sources by technological type of obsidian artifacts from Ceibal, Late Preclassic period.

Supplemental Table 4. Obsidian sources by technological type of obsidian artifacts from Ceibal, Terminal Preclassic period.

Supplemental Table 5. Obsidian sources by technological type of obsidian artifacts from Ceibal, Early Classic period.

Supplemental Table 6. Obsidian sources by technological type of obsidian artifacts from Ceibal, Late Classic period.

Supplemental Table 7. Obsidian sources by technological type of obsidian artifacts from Ceibal, Terminal Classic period.

\section{References Cited}

Aoyama, Kazuo

1999 Ancient Maya State, Urbanism, Exchange, and Craft Specialization: Chipped Stone Evidence from the Copán Valley and the La Entrada Region, Honduras. University of Pittsburgh Memoirs in Latin American Archaeology No. 12. Pittsburgh, Pennsylvania.

2001 Classic Maya State, Urbanism, and Exchange: Chipped Stone Evidence of the Copán Valley and Its Hinterland. American Anthropologist 103:346-360.

2004 El intercambio, producción y función de los artefactos de obsidiana del período formativo temprano en la costa del Pacífico de Guatemala: Un estudio diacrónico y análisis de las microhuellas de uso sobre la lítica de obsidiana del complejo San Jerónimo, Escuintla, Guatemala. Utz'ib 3(7):14-34.

2006 Political and Socioeconomic Implications of Classic Maya Lithic Artifacts from the Main Plaza of Aguateca, Guatemala. Journal de la Société des Américanistes 92:7-40.

2009a Elite Craft Producers, Artists, and Warriors at Aguateca: Lithic Analysis. Monographs of the Aguateca Archaeological Project First Phase, Vol. 2. University of Utah Press, Salt Lake City.

2009b Lítica. In La política de lugares y comunidades en la antigua sociedad Maya de Petexbatun: Las investigaciones del proyecto arqueológico Aguateca segunda fase, edited by Takeshi Inomata, Daniela Triadan, Erick M. Ponciano, and Kazuo Aoyama, pp. 276-297. Ministerio de Cultura y Deportes, Dirección General del Patrimonio Cultural y Natural, Instituto de Antropología e Historia, Guatemala.
Aoyama, Kazuo, and Juan Pedro Laporte

2009 Análisis de lítica menor elaborada con obsidiana en el sureste y centro-oeste de Petén, Guatemala. Utz'ib 4(6):11-40.

Aoyama, Kazuo, and Jessica Munson

2012 Ancient Maya Obsidian Exchange and Chipped Stone Production at Caobal, Guatemala. Mexicon 34:34-42.

Awe, Jaime, and Paul F. Healy

1994 Flakes to Blades? Middle Formative Development of Obsidian Artifacts in the Upper Belize River Valley. Latin American Antiquity 5:193-205.

Boksenbaum, Martin W., Paul Tolstoy, Garman Harbottle, Kimberlin Jerome, and Mary Neivens

1987 Obsidian Industries and Cultural Evolution in the Basin of Mexico Before 500 B.C. Journal of Field Archaeology 14:65-75.

Braswell, Geoffrey E.

2003 Obsidian Exchange Spheres of Postclassic Mesoamerica. In The Postclassic Mesoamerican World, edited by Michael Smith and Frances Berdan, pp. 131158. University of Utah Press, Salt Lake City.

2010 The Rise and Fall of Market Exchange: A Dynamic Approach to Ancient Maya Economy. In Archaeological Approaches to Market Exchange in Ancient Societies, edited by Christopher P. Garraty and Barbara L. Stark, pp. 127-140. University Press of Colorado, Boulder.

2011 Procurement and Production of Obsidian Artifacts at Calakmul. In The Technology of Maya Civilization: Political Economy and Beyond in Lithic Studies, edited by Zachary X. Hruby, Geoffrey E. Braswell, and Oswaldo Chinchilla Mazariegos, pp. 119-129. Equinox, Sheffield, UK.

Braswell, Geoffrey E., John E. Clark, Kazuo Aoyama, Heather I. McKillop, and Michael D. Glascock

2000 Determining the Geological Provenance of Obsidian Artifacts from the Maya Region: A Test of the Efficacy of Visual Sourcing. Latin American Antiquity 11:269282.

Brown, David O., Meredith L. Dreiss, and Richard E. Hughes 2004 Preclassic Obsidian Procurement and Utilization at the Maya Site of Colha, Belize. Latin American Antiquity 15:222-240.

Clark, John E., and Thomas A. Lee, Jr.

1984 Formative Obsidian Exchange and the Emergence of Public Economies in Chiapas, Mexico. In Trade and Exchange in Early Mesoamerica, edited by Kenneth G. Hirth, pp. 235-274. University of New Mexico Press, Albuquerque.

2007 The Changing Role of Obsidian Exchange in Central Chiapas. In Archaeology, Art, and Ethnogenesis in Mesoamerican Prehistory: Papers in Honor of Gareth W. Lowe, edited by Lynneth S. Lowe and Mary E. Pye, pp. 109-159. Papers of the New World Archaeological Foundation No. 68. Provo, Utah.

Cobean, Robert H., Michael D. Coe, Edward A. Parry Jr., Kark K. Turekian, and Dinkar P. Kharkar

1971 Obsidian Trade at San Lorenzo Tenochtitlan, Mexico. Science 174:666-671.

Cobean, Robert H., James R. Vogt, Michael D. Glascock, and Terrance L. Stocker

1991 High-Precision Trace-Element Characterization of Major Mesoamerican Obsidian Sources and Further Analyses of Artifacts from San Lorenzo Tenochtitlan, Mexico. Latin American Antiquity 2:69-91. 
Coe, Michael D., and Richard A. Diehl

1980 In the Land of the Olmec. University of Texas Press, Austin.

Drennan, Robert D., Philip T. Fitzgibbons, and Heinz Dehn 1990 Imports and Exports in Classic Mesoamerican Political Economy: The Tehuacan Valley and the Teotihuacan Obsidian Industry. In Research in Economic Anthropology, Vol. 12, edited by Barry Issac, pp. 177199. JAI Press, Greenwich, Connecticut.

Feinman, Gary M., Linda M. Nicholas, and Mark Golitko

2013 Exchange in the Valley of Oaxaca, Mexico: Late Classic Obsidian Procurement. Mexicon 35: 60-68.

Glascock, Michael D.

2002 Obsidian Provenance Research in the Americas. Accounts of Chemical Research 25:611-617.

Glascock, Michael D., Geoffrey E. Braswell, and Robert H. Cobean

1998 A Systematic Approach to Obsidian Source Characterization. In Archaeological Obsidian Studies: Method and Theory, edited by M. Steven Shackley, pp. 15-65. Plenum, New York.

Glascock, Michael D., and Jeffrey R. Ferguson

2012 Report on the Analysis of Obsidian Source Samples by Multiple Analytical Methods. Archaeometry Laboratory at the University of Missouri Research Reactor, Columbia, Missouri.

Golitko, Mark, and Gary M. Feinman

2015 Procurement and Distribution of Pre-Hispanic Mesoamerican Obsidian 900 BC-AD 1520: A Social Network Analysis. Journal of Archaeological Method and Theory 22: 206-247.

Healy, Paul F., Heather I. McKillop, and Bernie Walsh

1984 Analysis of Obsidian from Moho Cay, Belize: New Evidence on Classic Maya Trade Routes. Science 340:414-417.

Hirth, Kenneth G.

1996 Political Economy and Archaeology: Perspectives on Exchange and Production. Journal of Archaeological Research 4:203-239.

Hirth, Kenneth, Ann Cyphers, Robert Cobean, Jason De León, and Michael Glascock

2013 Early Olmec Obsidian Trade and Economic Organization at San Lorenzo. Journal of Archaeological Science 40:2784-2798.

Inomata, Takeshi

2012 La fundación y el desarrollo político durante el período preclásico en Ceibal. In La cuenca del Río de la Pasión: Estudios de arqueología y epigrafía Maya, edited by María Elena Vega and Lynneth S. Lowe, pp. 33-56. Universidad Nacional Autónoma de México, Mexico, D.F.

Inomata, Takeshi, Jessica MacLellan, Daniela Triadan, Melissa Burham, Kazuo Aoyama, Hiroo Nasu, Jessica Munson, Flory Pinzón, and Hitoshi Yonenobu

2015 Development of Sedentary Communities in the Maya Lowlands: Co-existing Mobile Groups and Public Ceremonies at Ceibal, Guatemala. Proceedings of the National Academy of Sciences 112(14):42684273.

Inomata, Takeshi, Raúl Ortiz, Bárbara Arroyo, and Eugenia J. Robinson

2014 Chronological Revision of Preclassic Kaminaljuyú, Guatemala: Implications for Social Processes in the Southern Maya Area. Latin American Antiquity 25:377408 .
Inomata, Takeshi, Daniela Triadan, Kazuo Aoyama, Víctor Castillo, and Hitoshi Yonenobu

2013 Early Ceremonial Constructions at Ceibal, Guatemala, and the Origins of Lowland Maya Civilization. Science 340:467-471.

Jackson, Thomas L., and Michael W. Love

1991 Blade Running: Middle Preclassic Obsidian Exchange and the Introduction of Prismatic Blades at La Blanca, Guatemala. Ancient Mesoamerica 2:47-59.

McAnany, Patricia A

2004 Obsidian Blades and Source Areas. In K'axob: Ritual, Work, and Family in an Ancient Maya Village, pp. 307-315. Cotsen Institute of Archaeology, University of California, Los Angeles.

McKillop, Heather

1996 Ancient Maya Trading Ports and the Integration of Long-Distance and Regional Economies: Wild Cane Cay in South-Coastal Belize. Ancient Mesoamerica $7: 49-62$.

Moholy-Nagy, Hattula

2003 The Artifacts of Tikal: Utilitarian Artifacts and Unworked Material. Tikal Report 27B. University of Pennsylvania Museum, Philadelphia.

Moholy-Nagy, Hattula, James Meierhoff, Mark Golitko, and Caleb Kestle

2013 An Analysis of pXRF Obsidian Source Attributions from Tikal, Guatemala. Latin American Antiquity 24:72-97.

Nelson, Fred W., Jr.

1985 Summary of the Results of Analysis of Obsidian Artifacts from the Maya Lowlands. Scanning Electron Microscopy 2:631-649.

Parry, William J.

1987 Chipped Stone Tools in Formative Oaxaca, Mexico: Their Procurement, Production and Use. Memoirs No. 20. Museum of Anthropology, University of Michigan, Ann Arbor.

Pastrana, Alejandro

1987 Análisis microscópico de la obsidiana. Revista Mexicana de Estudios Antropológicos 33(1):5-26.

Pierce, Daniel E.

2015 Visual and Geochemical Analyses of Obsidian Source Use at San Felipe Aztatán, Mexico. Journal of Anthropological Archaeology 40:266-269.

Pires-Ferreira, Jane Wheeler

1975 Formative Mesoamerican Exchange Networks with Special Reference to the Valley of Oaxaca. Memoirs No. 7. Museum of Anthropology, University of Michigan, Ann Arbor.

Rice, Prudence M., Helen V. Michel, Frank Asaro, and Fred Stross

1985 Provenience Analysis of Obsidians from the Central Peten Lakes Region, Guatemala. American Antiquity 50:591-604.

Rosenswig, Robert M.

2010 The Beginnings of Mesoamerican Civilization: Inter-Regional Interaction and the Olmec. Cambridge University Press, Cambridge.

Sabloff, Jeremy A.

1975 Excavations at Seibal, Department of Peten, Guatemala: Ceramics. Memoirs Vol. 13, No. 2. Peabody Museum, Harvard University, Cambridge, Massachusetts.

Spence, Michael W.

1996 Commodity or Gift: Teotihuacan Obsidian in the Maya Region. Latin American Antiquity 7:21-39. 
Willey, Gordon

1978 Excavations at Seibal, Department of Peten, Guatemala: Artifacts. Memoirs Vol. 14, No. 1. Peabody Museum, Harvard University, Cambridge, Massachusetts.

1990 Excavations at Seibal, Department of Peten, Guatemala: General Summary and Conclusions. Memoirs Vol. 17, No. 4. Peabody Museum, Harvard University, Cambridge, Massachusetts.
Zeitlin, Robert N.

1982 Toward a More Comprehensive Model of Interregional Commodity Distribution: Political Variables and Prehistoric Obsidian Procurement in Mesoamerica. American Antiquity 47:260-275.

Submitted May 19, 2016; Revised August 25, 2016; Accepted January 17, 2017 